\title{
Travel in Coptic Documentary Texts
}

\author{
Anna Selander
}

\section{Introduction}

This article seeks to provide a brief overview of the evidence for travel in Coptic documentary texts in late antique and early Islamic Egypt. ${ }^{1}$ To be able to form a representative source base for research on travelling it was necessary to read across all the published material, which amounted to over 7,800 texts. ${ }^{2}$ Of the 486 texts that I was able to collect from the sources that contain information about different aspects of travel, the earliest date is from the fourth century c.E., the latest from the ninth century. ${ }^{3}$ As is usual with the surviving Coptic material, most documents belong to the seventh and eighth centuries C.E. From the beginning it was clear that letters would be the best source to find out about the journeys people made. In fact, without these letters we would not-to a very significant degree-know that these journeys had been undertaken at all. Various reasons existed why one would mention a journey in a letter, including letting the addressee know that someone was on his or her way, or bidding the addressee pray for the traveler, etc. Often the addressee was asked to come or to send somebody. Problems encountered en route were also reported in letters, and in quite a number of them the writer announces that he has to cancel the planned journey.

In all, $88 \%$ of the data was drawn from letters, and the rest from other kinds of documents. The relative lack of documents dealing with journeys is due to the loss of relevant material (shipping contracts, etc.). What does

1 This article is based upon my master's thesis: Reisetätigkeit nach den koptischen dokumentarischen Texten, University of Vienna, 2006.

2 Since October 2005 there exists an online database of Coptic documentary texts, from which this estimate has been drawn (currently the number of documents is given to be more than 8,0oo). See http://dev.ulb.ac.be/philo/bad/copte/base.php?page=rechercher.php (25-08-2014).

3 Taken into account were all texts about private journeys written in Coptic. Since the range of dates runs to the ninth century, a few texts are included which are written in Coptic presumably by Muslims and/or people with Arabic names. E.g. CPR II 228 (8th century) where a certain Jazīd writes to someone called Abū 'Alī.

(C) ANNA SELANDER, 2015 | DOI:10.1163/9789004284340_007

This is an open access chapter distributed under the terms of the prevailing CC-BY-NC License at the time of publication. 
survive tends to deal principally — and this is the case with most of them - with some other subject. Sometimes, however, we can learn from the signatures of witnesses why a particular person signed the document including the reasons for making a journey. ${ }^{4}$ In the case of letters, certain information that can tell us about travelling has not been transmitted or has been lost altogether. This includes, in particular, the address. Place names for the addressee are also rarely mentioned in the body of the text since this was information both the addressee and recipient would have known anyway. The duration of a journey is also hardly ever given. Similarly, the mode of transport is seldom thought worthy of mention. Nevertheless, even if some details are missing, these texts offer a broad view across time of the nature of - and changes in - the experience of the Coptic-speaking part of Egypt's population as seen through their access to resources and freedom of movement.

The most common motives for travel in this period were, not surprisingly, trade and the dispatch of goods. However, I have excluded texts that treat mainly these subjects from the text corpus and have concentrated instead on private journeys, since these bring us closer to the personal priorities, motivations and day-to-day experience of Copts at this time. Also, we find a mass of texts among the Coptic documentary material, mainly letters, which deal with the transportation of goods, mostly requests for goods to be sent. But these texts hardly ever tell us anything about travel routes taken or the distances covered, so they have been excluded because of their low informational value. The large quantity of these (mostly short) texts, which number some thousand, was another reason for their exclusion. Of course, there are also texts in which a person travels and takes a small amount of goods with him. In these cases the text was taken into account because it documented the journey of a specific person, and therefore does not have the impersonality that one dealing with an unidentified messenger would have. ${ }^{5}$ For Coptic documentary texts dealing with trade and the dispatch of goods, a separate study is necessary, which would illustrate the economic aspects of trade in Egypt.

Besides the strictly private motivations for travel (journeys made on one's own initiative), I have also taken into account texts that document trips by agents on behalf of officials, clerics, estate owners or other employers.

4 E.g. P.KRU 65 (second half of the 7 th century), in which Pekosch writes that he had just come to the monastery to visit the father Jacob.

5 Texts that treat the transportation of wheat and corn in general have not been taken into account. 


\section{Reasons for Travel}

Travel was, in many ways, integral to life in Egypt. One common reason to undertake a journey was to deliver tax payments and such journeys could even stretch from Upper Egypt (e.g. Balāizah, Ishqūh/Aphroditō) to Babylon. ${ }^{6}$ Other reasons for travelling were the collection of money and also moving to another place, ${ }^{7}$ as is attested in the documents. The clergy were especially mobile since they tended to visit fellow monks and sometimes had to travel to celebrate masses for other villages. ${ }^{8}$ The bishops also regularly sent their staff on tours to inspect church personnel. ${ }^{9}$

A well-documented group concerns trips made to attend a feast. Nineteen texts ${ }^{10}$ give us information about the different feasts attended, including feasts of martyrs, divine services, Easter, as well as other feasts whose nature we cannot precisely determine. ${ }^{11}$ One especially interesting example is an invitation to a feast from the ninth century, written on the verso of an earlier Arabic text. ${ }^{12}$

6 In P.Bal. 240 (dating to between 675 and 775, like all other texts from Balāizah), for example, the trip starts at Ishqūh/Aphrodito and ends in Babylon, a distance of about $410 \mathrm{~km}$. Two other examples of long journeys are P.Lond. IV 1628 (beginning of the 8th century), where the same destinations are documented, and CPR II 228 (8th century), which attests a journey from Fayyūm/Arsinoe to Babylon (about $135 \mathrm{~km}$ ).

7 The letters O.Crum 385, 386 (both undated), O.Brit.Mus.Copt. II 27 (beginning of the 7 th century), and most likely O.Crum vc 67 (dating to between 619 and 629). Cf. also the letters concerning Frange discussed below. In documents e.g. P.Lond.Copt. I 449, $45^{2}$ (both undated), etc.

8 E.g. O.Brit.Mus.Copt. II 22 (beginning of the 7 th century), P.Mon.Epiph. 154 (7th century), O.Crum 53 (dating to about 60o), etc. For further texts relating to this topic, see Schmelz, Kirchliche $79-83$.

9 Krause, Die ägyptischen Klöster 225-236.

$10 \quad$ sв Kopt. II 897 (= P.Pisentius 71, undated); P.Mon.Apollo $5^{2}$ (6th-7th centuries); P.Ryl.Copt. 390 (9th century); O.Vind.Copt. 214 (7th-8th centuries); sB Kopt. II 814 (8th century); P.Sarga 94 (7th century?); O.Vind.Copt. 266 (7th-8th centuries); P.Mon.Epiph. 105; 131; 245 (all three 7 th century); O.CrumVC 53 ; P.Lond.Copt. I 547; O.CrumST 243 (all three undated); O.Ashm.Copt. 17 (7th-8th centuries); O.Brit.Mus.Copt. II 22 (beginning of the 7 th century); P.Moscow Copt. 55; 59; O. CrumVC 88; sB Kopt. II 893 (all undated). Interestingly, pilgrimage travel is a notable blank spot in the documents (see below). For this, inscriptions, archaeological sources and Greek papyri have instead to be brought into play.

P.Ryl.Copt. 390. Crum states: "Recto: an Arabic text (earlier), showing the name Nașr, كناب الى نصر." We do not know the further content of the text on the recto or whether the texts on recto and verso are related. Could "Nașr" be the sender of the invitation, or is the text 
Paul E. Kahle discussed elsewhere that the opening phrase (тнрнмн мак) indicates that a text is probably written by a Muslim, ${ }^{13}$ as we find in P.Bal. ${ }_{25} 6$ (end of 7 th/8th century) at the end of the text (line 5): дүळ тірнмн Nak. This is also how the ninth-century invitation starts. Also the lack of the usual cross, instead of which two diagonal lines appear, indicates that the text was possibly not written by a Christian or that the addressee was a Muslim. ${ }^{14}$ If we accept that one party was a Muslim, we can determine that the feast was certainly not a Christian religious one. The word п()d can stand for various feasts, most of them religious. But it was also used for birthdays, ${ }^{15}$ so maybe this text represents an invitation to a birthday party. Since the text itself is an invitation to a feast, which takes place the same day as the addressee receives the letter, the sender and the addressee must have lived relatively near to one other. el ępal means "come north" or "come south." As the practice in Upper Egypt was to use eepal by itself, ${ }^{16}$ we cannot be sure whether coming up or down is meant, and hence whether the traveler was going north or south. Walter Crum, the editor, could not interpret the words at the end of the text. Through a comparison of the formulary used in other texts, however, a plausible reading can be found. P.Mon.Apollo 16 (7th century) contains a parallel formula in line 10: $м \overline{\Pi P} 60 \overline{\mathrm{N}} \lambda-$ Tel ернс, meaning: "Stay not longer without coming south" (better expressed by "do not delay to come south"). This gives us the sentence, "Stay not longer without coming" (i.e. "do not delay to come"). So the writer of the ninth-century invitation again asks the addressee to come in any case!

of the recto earlier, as Crum states, and therefore not relevant? Due to renovation work in the past in John Rylands Library in Manchester, the text was not accessible.

13 As Kahle writes in the introduction to the letter P.Bal. 256: "the greeting at the end of the letter is 'peace unto you' which is the normal phrase found in letters written by Muslims."

14 See for this complicated and not yet completely satisfactorily solved question: Richter, Spätkoptische 213-230, especially $223 \mathrm{ff}$.

15 This meaning e.g. in P.Mon.Epiph. 253.13 (7th century).

16 It is interesting that ег епєснт (which actually means to come down) is used only five times in three texts: P.Lond.Copt. I 547, provenance Fayyūm; 1128 and 1124, both originating from Hermopolis, all undated. Whereas P.Lond.Copt. I 1124 remains undated, it can be said that P.Lond.Copt. I 1128 is to be dated sometime after the Arab conquest (here also the two strokes are used, and the name is Arabic. Here we also find the rendering тірнмн nak). Due to the limited sources we cannot determine why ев епеснт was used only very seldomly. The reason could be of a geographical nature: it seems that in Lower Egypt to Hermopolis it was used even though not often, whereas up till now from Hermopolis to Aswan explicitly el e2pal (in connection with travel) was applied. 
Another important Coptic stimulus to travel was the settling of arguments. ${ }^{17}$ As a first step one party would invite his opponent to come and try to settle the quarrel. In cases where an arrangement could not be reached the matter was then referred, either via a letter or in person, for example to a senior cleric who would be asked to adjudicate. ${ }^{18}$ O.Vind.Copt. $25^{8}$ (7th-8th centuries), in which a certain Anup and a woman are engaged in a dispute, is a good example of this procedure. To make his case, Anup travels south to report the details of the disagreement to a person who is addressed as "your fatherhood" - presumably a high-ranking cleric, most likely to be the abbot of a monastery. Reacting to Anup's testimony and to present her side of the story, the woman then writes a letter to the cleric. As well as cases such as this, we have instances of divorces and the dissolution of marriages precipitating similar journeys. ${ }^{19}$

A well-represented group of texts shows that travelling to find work or to get to a place of work was an important inducement to travel in late antique Egypt. The texts show that for this reason larger distances were also covered. P.Mon.Epiph. 296 ( $7_{\text {th century }}^{20}$ ) gives, for example, a distance of $40 \mathrm{~km}$ that had to be covered first by the messenger and then by the baker, who was asked to come from Koptos to Thebes to make bread and butter for the monastery. Of course, there must also have been a considerable number of official trips, but these are not so well attested in the Coptic documentary texts.

17 P.Köln̈̈gypt. 17 (provenance unknown); P.Mon.Epiph. 96; 189; 262; 267; 300 (Thebes, monastery of Epiphanius); 438 (all 7th century); O.Vind.Copt. 212; 218; 258 (all three 7th-8th centuries); O.CrumST 181 (provenance unknown, end of 6th-7th centuries); BKU III 338 (during Persian occupation); 403 (undated); O.Crum 48 (dating to about 6oo); O.Crum Ad. 46 (undated).

18 E.g. P.Mon.Epiph. 189 (7th century). For the role of monks and clerics in settlement of arguments, see Schmelz, Kirchliche $272-288$.

19 P.Mon.Epiph. 161 (7th century). To ligitation see futher: Allam, Civil jurisdiction 4.

20 Peel (Dayr Epiphanius 80o-802) assumed (according to Crum and Winlock) that all texts from the so-called Monastery of Epiphanius date between 580 and 640 . That this is not the case could be shown through the excavation of тT 29 (see page 89), which makes clear that Frange lived there in the eighth century. And since Frange is corresponding with members of the monastery, they are contemporaneous, and therefore the monastery still existed at least in the eighth century. All texts, in which Frange is mentioned, are therefore to be redated to the eighth century. Of course, also other texts from the monastery might be from a later date. 


\section{Modes of Transport}

The mode of transport, where it is known or can be inferred, also offers important insights, but, surprisingly, only a few texts give us clear information on this. This is because in most texts-as seen in the case of P.Ryl.Copt. 390 aboveonly vague co-ordinates, such as "to go north" and "to go south," are given, even in the case of journeys between the Nile Valley and the oases, since this was the primary axis of geographical orientation for Egyptians. ${ }^{21}$ In Old Egyptian the usual words for going north and south were determined by the sign of a ship. But the Coptic expression offers no clues as to whether these trips were made by ship, camel or donkey. Indeed none of the texts surveyed using the phrase explains the employed method. Here only the distance or the time span needed for the trip-if known - can help to determine what is more likely. From the reading of the texts in which no remarks about the time required or the distance covered have been made, the cumulative impression is that most of the documented trips were made on foot.

About forty documents in the corpus relate to ships, ferries and sailors, but as the texts show, the use of ships was largely restricted to the transportation of goods, whereas private journeys by boat are not often attested. The most important role for the use of a ship was the transportation of goods, especially corn. That the ship was not the first choice for private individuals is indicated by the much higher price paid for boat travel than transportation by donkey or camel, or on foot. An additional reason for this result is probably the nature of the source material, which, for the most part, deals with journeys that covered a distance of less than one day's travel. The texts also speak of the Arab naval fleet, for which Egyptians from all parts of Egypt were recruited.22

Only three texts speak of the use of a ferry, and from them we see that crossing the Nile was relatively cheap. ${ }^{23}$ This shows on the other hand what a limited view the extant corpus gives us, since ferries were naturally very important in Egypt. Therefore, it can be inferred that a receipt was not issued for every crossing, and for this reason we mostly get information - as is the case of P.Bal. 291 (end of seventh-eighth centuries) — only if a receipt was needed for

21 See Alcock and Funk in P.Kellis v, p. 13: "The oasis dwellers regarded themselves as separate from Egypt, which was conceived as a north-south axis stretching from the area where the trade routes reached the valley."

22 See for these texts, P.Lond. Iv.

23 P.Bal. 291 (end of the 7 th century-beginning of the 8th century); P.Ryl.Copt. 334 (8th century); sB Kopt. II 889 (9th century). 
the account books of a monastery, or as a bill for a business partner or employer. After all, most of the texts in the corpus are letters, in which a mention of having taken a ferry would not be especially important, except perhaps for business reasons.

The best source we have for travelling by boat is O.Medin.HabuCopt. 82 (seventh-eighth centuries), which documents the $390 \mathrm{~km}$ journey from Thebes to Antinoe. This shipping contract is unique among the Coptic documentary texts for the large amount of information it contains, including the journey's starting point and destination, the names of the people involved, the costs and even the means of travel. Such a quantity of data is a result of its nature as a document, since letters tend only to transmit information that is necessary and not yet known by the addressee. ${ }^{24}$ Steve Vinson comments as follows: "This text is a short shipping contract, in which a captain agrees to charter his vessel for the hauling of an unspecified cargo. It appears as though the arrangement actually makes the captain and charterer into temporary partners. After the captain has collected his freight fee ( $3 / 4$ solidus), any additional revenues from passengers and any operational expenses incurred en route are to be shared on a $5^{0-50}$ basis. The upshot is that, at least from the Graeco-Roman period into the early Arab period, vessel income seems often to have been split on a $5^{0-50}$ basis by the owner and crew." 25

Attestations of the use of camels and donkeys are also not often found in the letters. ${ }^{26}$ But since most of the distances covered are rather small (less than a day's travelling), it is very likely that most of the small-scale travel was done by camel, donkey or on foot. Even larger distances were covered that way. As texts show, monasteries hold a key position in such travel, since they had their own camels and donkeys along with camel drivers. Often monks from other monasteries, and perhaps private people too, borrowed an animal to go on a trip. In this way camels played a critical role in long-distance travel, especially from an oasis to the Nile Valley. For journeys from an oasis to the Nile Valley, the most important sources are the texts from Kellis in the Dakhla Oasis, where a Manichaean community had its base. Although the distance was long-130 km,

\footnotetext{
24 See below, for the edition and translation.

25 Vinson, The Nile 75-76.

26 At least with regard to travel by those whose main priority is not the transportation of goods. Examples of texts in which donkeys and camels appear are O.CrumVC 68, O.Theb. 27 (both 7th-8th centuries, see for this text also P.Mon.Epiph.1, p. 182), very likely P.Lond.Copt. I 590 (undated, paper), and 529 (Arab period). In Spiegelberg, Besprechung 68-69 we find a text in which it is stated that the journey fails because no donkey could be found (the translation was corrected by Crum in Winlock and Crum, The monastery 182).
} 
and one would have needed six to ten days with a donkey and less with a camel, ${ }^{27}$ which was preferred-it seems to be the case that travel, and in turn communication, occurred regularly between the oases and the Nile Valley.

\section{Travel Difficulties}

However one travelled, making trips in Egypt was never entirely easy. Generally in the texts it is considered to be difficult, wearying and often demanding significant effort and sacrifice. This attitude tends to be reflected in the oftenused phrase, "be so kind and trouble yourself to come," or its variants, "find a way to come," "find an opportunity to come," and so on. ${ }^{28}$ It was not only the Copts who conceived of trips in this way, as Greek texts in which the sender asks the addressee likewise to "trouble himself to go somewhere" revealed. ${ }^{29}$ That this phrase was not only used as a courtesy is also shown in some texts in which the writer explicitly says that complications on the journey, especially the roads, prevented him from getting somewhere. ${ }^{30}$ The text O.Crum Ad. 59 (dating from between 578 and 605) even demonstrates that a whole monastery was shifted from a somewhat inaccessible site in the desert behind Jeme for this reason. The order was given by the patriarch Damianos (in office 578-605) himself to improve the accessibility for the messengers who had to deliver the festal epistle throughout the whole country every year. ${ }^{31}$

\section{Illness}

Another major thematic group of texts reveals planned trips that had to be cancelled due to illness. In 12 instances the letter-writer says he cannot make a journey because he has become ill. ${ }^{32}$ Among these illnesses we find problems

$27 \quad$ P.Kellis $\mathrm{V}, 12$.

28 E.g. like P.MoscowCopt. 55 (undated), v. 20-22 дрı тагдпн |

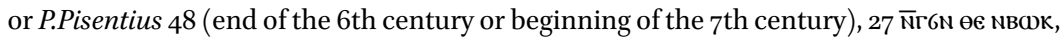
or a construction with GN TYחoc, etc.

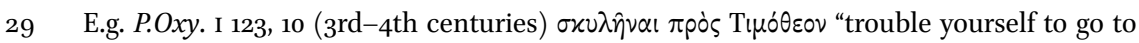
Timotheos."

$30 \quad$ P.Mon.Epiph. 473 (7th century) and O.Crum 253 (provenance unknown, undated).

31 Krause, Die ägyptischen Kloster 204.

$32 \quad$ P.Mon.Epiph. 162; 168; 277 (all three 7th century); O.CrumVC 38 (undated), P.Sarga 93 (7th century?); P.Bal. 245 (end of the 7 th century, 8th century); P.Mich.Copt. 13 (8th century?); P.Ryl.Copt. 273 (4th-5th century); sB Kopt. II 893; O.CrumST 363; P.MoscowCopt. 59; sв Kopt. II 854 (all undated). 
with the feet ${ }^{33}$ and in sB Kopt. II 854 (undated) the sender complains that he has been seriously ill for two weeks with fever. Two texts inform us that the parties have become ill during the journey. ${ }^{34}$ O.CrumVC 35 (undated) even tells us about the death of a man's business partner during a trip that had led them north. The text is an oath in which the man had to swear that he did not conceal any of the deceased's belongings from his heirs. Unfortunately, we do not learn what happened to the dead man's body. Many of these texts show that it was important for the one who fell ill to have a cleric pray for him so that God might relieve him of his illness. ${ }^{35}$

\section{Crime}

Brigandage and robbery were also persistent concerns for travelers. O.CrumST 390 (undated) seems to indicate an example of mugging. In this short and enigmatic text, a monk recounts to a fellow monk an episode on the road to Alexandria in which he was waylaid by six "devils" and only in the last moment managed to escape. The monk takes no chances: "I ran," he says. That he must have survived the incident is, of course, shown by the fact that he was writing at all. But how the story ends we do not know, since the letter is unfortunately broken and the end is missing. ${ }^{36}$

Three other letters document the dangers of leaving home. ${ }^{37}$ In these the writers declare their wish to go on a journey, but claim they cannot do so for fear that their homes and belongings would be robbed in their absence. That only four texts among the Coptic letters deal with criminality of this type does not mean, of course, that crimes did not occur more often. In fact, the opposite seems to be the case: "Zieht man die bereits im 7. Jh. herrschenden Verhältnisse in Betracht, wofür belegt ist, daß viele Menschen durch Überfälle herumstreichender Banden (im 8. Jh. auch durch hohe Steuerlasten) in Not gerieten," ${ }^{38}$ we can assume that a lot of incidents of mugging took place.

33 P.Mon.Epiph. 277 (7th century); O.CrumVC 38 (undated).

34 P.MoscowCopt. 11 (4th-5th century); P.Mon.Epiph. 249 (7th century).

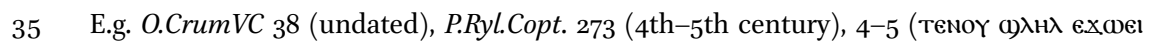
| мтепм[оүте †6] ом ма! +нноү ()арок: "now pray for me that god gives me strength that I come to you"), and O.CrumST 186 (undated). About illness among the Copts, cf. P.Harrauer 213-222.

$36 \quad$ See below for the edition and translation.

37 P.Mon.Epiph. 222 (7th century), O.CrumVC 98, and O.Crum Ad. 46 (both undated).

$38 \quad$ O.Brit.Mus.Copt. II 27. 


\section{Travel across Time}

\section{Pre-Conquest Egypt}

From the fourth and fifth centuries only a few texts have survived, leaving us with a limited picture of travel in this period. ${ }^{39}$ The most important group comprises the letters and documents from the Manichean community in Kellis in the Dakhla Oasis, which date from the fourth century. ${ }^{40}$ The texts - mostly letters-document the correspondence between family members who had stayed behind in Kellis and the men who were in the Nile Valley. They show us journeys made from Kellis to Antinoe, Hermopolis and Assiut, and the trips made by the men while they were in the Valley, again mostly from Antinoe to Hermopolis and to Assiut. ${ }^{41}$ As well as this, the letters inform us about the small-scale journeys between the different villages of the oasis. Especially interesting, because of his frequent travels in the Nile Valley, is the person called "the master" (пса 2 ). We hear, for example, of him taking Piene, who joins his entourage, with him to learn Latin, ${ }^{42}$ and in another letter we find out where their journey led, namely Alexandria. ${ }^{43}$ Yet another letter tells us that Piene and the master left Antinoe, so we know that the trip went from Antinoe to Alexandria. ${ }^{44}$ That Piene and the master arrived in Alexandria, and that Piene continued to live there safely, is reported again in another letter, which reports that fellow brothers come from Alexandria to the south bringing news and a letter from him. We also hear that Piene intends to come south again. ${ }^{45}$

Just as is the case for the forth and fifth centuries, only a few Coptic papyri have survived from the sixth century. An additional problem is the uncertain dating, which concerns above all the placing of the texts between the fifth and the sixth centuries. Judging from those few and often not exactly dated texts, it seems that travelling was equally possible as before this age and that no significant changes or restrictions took place. travelling, which are: 19, 20, 22, 24, 25, 28, 29, 31, 39, 40, 5 . in the Nile Valley) who writes to Maria in Kellis.

$42 \quad$ P.Kellis v 20.

43 P.Kellis v 29.

44 P.Kellis v 25.

45 P.Kellis V 24. 
The next period which is closely defined again and about which several papyri give us valuable information is the Persian occupation. ${ }^{46}$ Under Persian rule the relative good mobility of the people in Egypt seems to have been somewhat curtailed. As some texts make fairly clear, during the occupation finding transport and undertaking journeys could be complicated. Document sв Kopt. I 36 informs us that a woman with the name Thekla, having sold part of her house in Edfu, made preparations to leave the city. The text reports that she wanted to travel by ship, but could not find one anywhere, and so was forced to go instead by foot. Given that her final destination was a village named Great Beschin (today's al-Fashn) $32 \mathrm{~km}$ north of Oxyrhynchos, she would have had to have walked an extraordinary $472 \mathrm{~km}$, which would have taken her at least 15 and a half days. The letter P.Mon.Epiph. 324 raises the question of whether travel restrictions were imposed on the population, since the writer reports to a monk that he has asked someone to write a letter to "the Persian" in Thebes in order to let him go south to fetch some corn. This person indeed wrote the letter to the Persian official. But because the letter is very short-a part of it seems to be missing - we do not know the relationship of the man to the Persian.

O.CrumVC 67 from the Persian period shows clearly—and the background of another text makes it likely-that at this time there were problems with the food supply in Upper Egypt. The man reports in a letter that he travelled north because, with no corn coming south, he could not feed his children. So a trip was made to keep the family alive. Furthermore, we get indications from the sources that there had been riots directed against the Persians. A text confirming this is $B K U$ III 338 , in which someone, presumably a bishop, tries to find a way to settle a quarrel between the Persians and the leaders of the riots, which had already resulted in the partial destruction of the city of Hermopolis. That the bishop was not totally free in his decisions is shown by the fact that the Persians told him they would take his son as a hostage until the matter was resolved. The texts from the Monastery of Epiphanius show that the invasion was remembered so well by the people that an incident that had happened before the invasion and was reported somewhat later was referred to as "before the Persians came south."47

46 For a compilation of the Greek, Coptic and Persian documents which date from the time of the Persian occupation, see MacCoull, Coptic Egypt 307-313. The Coptic sources can be found on page 312. To these have to be added O.CrumVC 67 and sB Kopt. II 846. 
The impact of the Persian occupation on Egyptians' mobility and prosperity provides a useful model against which to assess the effect of the Muslim conquest. How did the new order under which Egypt's Christians found themselves affect their access to resources and freedom of movement? Did the nature of travel change?

\section{Travel under the Arabs}

One of the most significant Muslim innovations affecting the flow of people was the introduction in the eighth century of the so-called sigillion ( $\sigma \gamma^{\prime} i \lambda$ $\lambda(0 v),{ }^{48}$ or, in Arabic, sijill (سبلّ) or permit that authorised someone to leave his or her tax district. ${ }^{51}$ The best evidence we have that the sigillion cannot be underestimated as an obstacle to mobility comes from P.CLT 3 (728/729 or $743 / 744)$, which deals with a group of Theban monks who wanted to go on a business trip to the Fayyūm to sell their ropes and wares, but could not do so without having first been equipped with a passport. ${ }^{52}$ As an Arabic source informs us, ${ }^{53}$ getting such a document could take up to two months, for the applicant had to meet various requirements beforehand. First, he had to prove (through a tax receipt) that he had no tax liabilities. Then he had to nominate, for the future tax that would accrue during his absence, someone who would be willing to sign a document guaranteeing his tax payments. "Diese Bürgschaftsurkunde mußte dem Pagarchen (Amīr) vorgelegt werden, dann konnte der Reisepaß unter Mitwirkung der Ortsbehörde beantragt werden und durch den Pagarchen (Amīr) ausgestellt werden." ${ }^{54}$ This procedure had to be strictly followed. To date, no evidence has been found that suggests the idea of a passport had existed before the beginning of the eighth century.

48 For all documents with a sigillion in the meaning of "passport," see Förster, Wörterbuch 726 .

49 Term used by Sāwīrus ibn al-Muqaffac, History 69, 70.

50 Schaten, Reiseformalitäten 93 n. 11 .

$5^{1}$ Rāgib, Sauf-conduits $145^{-146}$ favours the translation 'permit' because "il ne permettait au porteur que de se rendre en un lieu désigné du pays et d'y séjourner pour y travailler pendant une période déterminée, alors que le passport appelé ğawāz ou barāa lui conférait le droit de franchir les frontières."

$5^{2}$ The excavation of Deir el-Bachit in Dra' Abu el Naga, ongoing since 2004, of the Ludwig Maximilian University of Munich could identify the site as the monastery of Apa Paulos, from where the monks mentioned in this text, came from.

53 Sawīrus ibn al-Muqaffa', History $69-70$.

54 Schaten, Reiseformalitäten 93 . 
During the excavations of the Mission archéologique dans la nécropole thébaine (MANT) ${ }^{55}$ a number of Coptic papyri were found in Theban tomb тт 29. This old Egyptian tomb of the vizier Amenemope was inhabited in the first half of the eight century by the semi-anachorite and monk Frange. The texts found in TT 29 shed more light on the circumstances of travel in the Theban region. In a clay-basin, in the hall of this tomb (in layer 159), more than a dozen fragmentary papyri were discovered - some with preserved seal-that Frange had used to stuff book covers. One of the papyri is completely preserved and shows that the documents contained in them were short and businesslike: "N' empêche pas Papas et Theodorake de se rendre à Djémé, car c' est pour leur travail (?) qu' ils y vont. Mois d' Athyr, le 3. 3e (année de) l'indiction. A remettre à Halakotsé, de la part de Pha .... ${ }^{56}$ While the exact circumstances in which these documents were issued is not known yet, it is likely that they had something to do with taxes comparable with the above mentioned permits. Whereas the Arabic safe-conducts ${ }^{57}$ are very precise concerning the time and place that they covered, these Coptic "permits" in the form of short requests for passage are not. Nevertheless we should probably follow Rāgib in understanding these texts as the Coptic equivalence of the Arabic jawāz or barāa a, that is to say passports, which allow the population to cross frontiers. ${ }^{58}$ Boud'hors assumes that there must have been a certain road check (or toll station) around Jeme. ${ }^{59}$ Since the documents were written on papyrus and were sealed, their character was certainly official. They were written - in a number of cases the name of the addressee is preserved - to an official named Halakotse, obviously the person in charge of the checkpoint allowing people into Jeme and/or to go on a trip to the south. The writer of the letters must have been an official, too, who forwarded the request ensuring that the person or persons mentioned in these documents could go to the places they wanted, to Halakotse. Some of the letters mention a reason for those travels, like work or the need to pay taxes. In one text (P.TT 29 inv. 295028), it is stated that Halakotse allowed Schenute to go home to the south, since he was living in the nome of Hermonth. Since these letters were of short use (after processing the request, the letter was not important anymore), Halakotse

55 Under the auspices of the universities of Brussels and Liège. See http://www.ulb.ac.be/ rech/inventaire/projets/4/PR3344.html and http://www.egypto.ulg.ac.be/necropole.htm.

56 Boud'hors, L' apport de papyrus 120 (P.TT 29 inv. 291972).

57 For the safe-conducts written in Arabic, see Rāgib, Sauf-conduits 143-168.

58 For the passport, see above note 51 .

59 Boud'hors, L'apport de papyrus 123. 
gave or sold the papyri at some point to Frange, who then applied them in making book covers. ${ }^{60}$

Another late phenomenon is the logos ( $\lambda$ óros,, 11 "Schutzbrief") in the Coptic documentary texts, which functions as a guarantee of unimpeded passage. ${ }^{62}$ Most of these documents were written to ensure that those whose freedom was in some danger - for example, a debtor or opponent in a quarrel or a leader of a riot-could return safely to their home villages. Sometimes, in the case of debtors, the debts were even forgiven; in other cases, a reduction of the debt or postponement of payment was granted. The purpose of these logo $i$ was to prevent members of a community's tax-paying population being lost, since the tax burden of the person who had fled would then fall on the village. In Greek

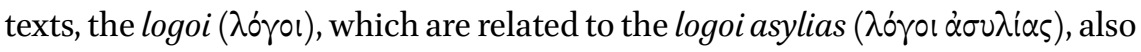
appear rather late, although earlier than their Coptic equivalent—sometime in the middle of the sixth century. ${ }^{63}$ The Greek documents, by contrast, were only issued by officials.

Although Coptic logoi texts are quite numerous, they only offer limited information about travelling. We can infer that someone fled and possibly returned, but the distances they travelled and the places in which they sought refuge remain unknown. Only one related pair of texts, P.Schutzbriefe $53 \mathrm{~b}$ and $53 \mathrm{c}(=$ O.Vind.Copt. 65 (7th-8th centuries)), supplies the information that the addressee of the logos is permitted to come south to the people of the island of Ombos.

Most of the logoi tell the addressee to come home without fear. But two texts use an identical and special form of request. O.Brit.Mus.Copt. I s. 99, 2 [5894] (7th-8th century), v. 2-3, says: may go north, you may go south." ${ }^{64}$ Since other texts use this phrase as well in a similar wording, its meaning is fairly clear. The person who requests an official or cleric to write a logos promise wants to indicate by this phrasing that the debtor or the like is free to go wherever he wishes.

6o Both texts, and excavated material of the тт 29, prove that Frange not only produced textiles and ropes, but also made bookbindings and bookcovers (O.Frangé 19-20).

61 For documents of this kind, see Förster, Wörterbuch 478-479.

62 The Coptic logoi texts (Schutzbriefe) range from the seventh to the ninth centuries. sB Kopt. II 914 is dated to the first half of the seventh century. See on the Schutzbriefe, Delattre, Les "lettres de protection" $173-178$ and lately Selander, Die koptischen.

63 Palme, Asyl und Schutzbrief 229.

64 The other text is also a Schutzbrief: O.Crum 108 (= P.Schutzbriefe 40, undated) lines $3^{-4}$ say: мгвок емгнт | [N]гвюК ернс. 


\section{Remarks on Time and Place in the Texts}

Nomenclature is often not as helpful in fixing places as one might hope. Typically people are identified by their father's name and only occasionally by their place of origin. For determining the route of a journey, this practice has to be treated very cautiously since it means that a person's current whereabouts, and especially the starting point of a trip he is undertaking, cannot be inferred from his name alone. In the case of the man named Frange, who says he is "the man from Medamoud" (примпєтємоүт) but now residing in an old Egyptian tomb on the hill of Jeme, ${ }^{65}$ the place of origin and place of residence are not far away from each other. But from deeds, for which an individual's personal data were more relevant, we know that the place of origin and the current whereabouts could differ enormously. ${ }^{66}$

About some aspects of travel in the Coptic period we are, however, only scarcely enlightened by the Coptic documentary texts, or not at all. For example, this is the case with journeys which led the travelers abroad. Here only a single mention has been found. The above mentioned Frange is known to have travelled to Jerusalem. From the text O.Frangé 20 we learn that Frange wanted to go to Jerusalem, which was forbidden by the Elders. We also hear that Frange had planned to travel together with the correspondent of the letter on this far trip. When Frange was stopped from going, he writes the addressee that he too should stay home this year. That Frange was able to travel to Jerusalem at some other point we learn through the text O.Frangé 51 , where he states that the addressee David should send him two things that Frange had brought earlier from Jerusalem. We do not know exactly why Frange was not allowed to go to Jerusalem in the first context. Boud'hors and Heurtel assume that either an administrative reason (leaving the tax district) might have prevented Frange from leaving or that the religious authorities prohibited it. We can only assume that his trip to the Holy City was a pilgrimage, but as we learn from the latter text Frange also brought home useful devices.

The Coptic term оммм, translated with 'abroad' or 'foreign,' does not, however, necessarily mean a place outside Egypt. Rather, it generally denotes a place that is unknown to the traveler but that is located within Egypt. Even a

65 For Frange, see e.g. Heurtel, Que fait Frange 177-204 and O.Frangé. And for his designation of origin and current whereabouts, see Heurtel, Que fait Frange 187: 0. 29840, and O.Frangé $10-12$.

66 E.g. P.Lond. IV 1628 (beginning of the 8th century), where two witnesses have Aphrodito as place of origin, but sign the document in Babylon; sв Kopt. I 242 (Edfu, 649 C.E.), where the sailor is after all from Edfu and signs a receipt in Esna, etc. 
place or region in the vicinity of a well-known city but with which the traveler or city-dweller was unfamiliar could be described as œммо. 'Abroad' was also used when someone went into the desert to live as a hermit.

About a tenth of the texts surveyed specify the time at which the sender of the letter intends to visit the addressee. Sometimes even the main purpose of the letter was to transmit this information. Mostly we find announcements of what time somebody will come, or requests that the addressee should meet the writer of the letter on a certain day or at a certain time. We also find statements that somebody plans to go to a certain place to inform the other party that he will not be at home for a certain period of time. Not that often we find the statement that somebody should have come at a certain time, but could not come and now writes when he will come instead. At last we find letters where the writer tells the addressee when he went to a certain place.

For these texts, where the writers speak of coming to the addressee on the following day, we can determine that the duration of the journey cannot have been longer than one day and therefore a short distance was covered. In some texts, in which a specific date is mentioned, this is usually because it is a date on which an agreement has been made to start work. Five texts even document that the journey would be undertaken at night if the circumstances made it necessary. ${ }^{67}$

\section{Comparison to Greek Texts}

To get additional information about travelling in Roman and late antique Egypt it would also be necessary to undertake a thorough study of the Greek texts related to travel. ${ }^{68}$ This has still to be done. But from Chrisi Kotsifou's work ${ }^{69}$ it can already be seen that certain aspects, which are not to be found in the Coptic text corpus, are present in the Greek texts. In the Greek texts we find information about the travels of athletes and entertainers, travels whose goal was tourism, holidaying, escaping the hot weather (P.Oxy. XxxIV 2727, 3rd-4th centuries) or oracle-questioning, and travels abroad. We also find prayers that a trip will take place and will be safe, information about the weather and sailing conditions (favourable winds, Nile level), information that sailing at night was

$67 \quad$ P.Lond.Copt. I 529 (Arab period); O.Mich.Copt. 7 (7th century); 9 (6th century?); P.Pisentius 5 (end of the 6th century or beginning of the 7 th century); P.Mon.Epiph. 134 ( 7 th century).

68 For transportation in general, see e.g. Bagnall, Egypt 34-40.

69 Kotsifou, Papyrological evidence $57-64$. 
prohibited and that attacks from pirates were taking place. For the lack of such references in the Coptic documentary texts various reasons can be assumed. For example, change in religious practice accounts for the absence of questions to oracles. The almost complete absence of references to pilgrimages though is harder to explain, since pilgrimage was an important reason for undertaking a journey, and one would expect this to be reflected more strongly in the letters. But we probably have to assume a simple gap in the record, remembering that about six times as many Greek than Coptic documentary texts have been published to date.

\section{Conclusion}

Travel has been essential for the economic and social life of Egypt from pharaonic times ${ }^{70}$ up until the present day. We can say that most of the conditions of travel, such as the available means of transport, did not change much (technically) from the pharaonic period up to and including the pre-modern age. Only in the more industrialised conditions of our own age have the speed, ease and cost of travel significantly changed. In the time span covered here it can be said that although travelling was somewhat arduous, since no official transport system existed for the rural and non-élite populations of Egypt, it is noteworthy that people were to a great extent mobile. For the common citizen, who did not have access to the transport system controlled and supported by the state, travelling meant taking responsibility for his or her own arrangements, including finding suitable donkeys or a ship's captain willing to take on passengers (and in this case, concluding the necessary contract).

Another possibility for those not able to afford a ship's passage or not needing one-since only longer distances were covered this way due to the expense-was to hire a transport animal from a monastery. The church and the monasteries had their own stock of animals—including camels and ships ${ }^{71}$ which could be rented. These were needed to fulfill their many pastoral duties, including, for example, distributing the annual festal epistle of the archbishop of Alexandria across the breadth of Egypt, a significant operation. It is not surprising, therefore, that the clergy and monks were especially mobile. Only monks had to ask for allowance before they wanted to travel from their superiors in the monastery. For small-scale journeys—and in some cases also for long

\footnotetext{
$70 \quad$ Köpp-Junk, Reisen.

71 For ships in the property of churches and monasteries, see Bagnall, Egypt 37 with footnote 157 .
} 
distances if no other mode of transport was available or affordable-common Egyptians went by foot. The exact amount of travelling done with each mode of transport remains unfortunately unclear in most of the Coptic documentary texts. Also, the duration of a single trip is hardly ever stated in the texts.

The reason for our poor knowledge of the respective usage of different modes of transport and the duration of journeys lies in the nature of the source material, which consists mostly of letters. In letters, people in antiquity tended to transmit only the most necessary information to the addressee, making it necessary, for example, for the receiving party to know when the traveler would reach his destination but not how long the whole trip would last. Also, the mode of transport would not be of special interest to the reader of a letter. What we are very well informed about, however, was why people undertook their journeys.

Whereas the overall conditions of travelling stayed pretty much constant during the whole of antiquity, it is especially interesting to see what impact the changing governments of Egypt had on the conditions of travel. ${ }^{72}$ As we already have seen, the Persian period is marked by the shortages in the supply of ships. At this time the supply of food also ceases to be regular in southern Egypt, leading people to want to leave Upper Egypt. The situation becomes so critical people are forced to walk if they want to reach their destination. As some texts suggest, there also seems to have been restrictions on travelling.

After the Arab invasion of Egypt there is another period of reduced mobility. The worsening of the economic situation in the seventh and eighth centuries can be seen in the increasing number of fugitives attempting to escape the increasing tax load. The logoi, although already starting to be issued in the first half of the seventh century, become more common after the Arab invasion. In order to better control the flow of people - rural exodus has been a long-standing problem in Egypt since Ptolemaic times - the Arab government introduced the permit or passport. Whereas the necessary papers could be put together with the help of local officials and were written in Coptic, the actual passport document could only be issued in the office of the pagarch and was therefore only in Arabic. This meant, of course, undertaking a journey required considerable expenditure. Such passports were restricted in time span, most often to three months, and had to be kept during the whole time of the journey, since losing the document could have severe consequences. They include the names of the issuing official of the amir (pagarch), the name of the passport-

72 The Coptic material does not give enough information to be able to say if the transport infrastructure (e.g. quality of the roads, frequency of way-stations, control of brigandage, etc.) improved or deteriorated in the Arab period. For this dimension official documents are more likely to be revealing. 
holder, a physical description, the reason for travel (usually for the bearer to be able to earn his living and hence pay the next poll-tax), and the areas in which he was permitted to travel. At the end followed a statement that no harm should be done to him during the document's specified span of validity. ${ }^{73}$ But whereas the time span granted for a journey was restricted, the distances a traveler was allowed to cover were obviously not. As we see in P.CLT $3(728 / 729$ or $743 / 44$ ), the monks wanting to travel from Thebes to Fayyüm had already been recommended by the local authorities, which suggests that the officials of the amir would most likely have agreed to issue the passport. Although the passport system gave the government absolute control over (legal) travel, its aim was more to ensure the tax-payment of the population of Egypt. Less formal laissez-passers in Coptic, found in an ancient Egyptian tomb, seem to have functioned at a very local level and were used to allow the population from Jeme free passage in the early eighth century.

In the seventh century gangs roaming the countryside became an increasing danger. At times in the Muslim period too there seem to have been shortages in the supply of donkeys or at least an increase in the amirs' request for donkeys to be provided by the people for official use. ${ }^{74}$ Consequently, people were afraid of losing their animals for certain periods, which meant, of course, economic discomfort. Taking all this together, it seems to be clear that travelling in the seventh and eight centuries was even more difficult than in the times before.

The example of the passport also shows the necessity of combining sources of different languages to be able to draw a more complete picture of travel in late antiquity. The Greek material serves above all to illuminate the earlier period, whereas the Coptic material is somewhat scarce, and the inclusion of Arab sources is necessary to gain greater insight into the official issuing of documents and state policy. This is also true for the earlier Greek documents, since they too give us insight into official policy. Coptic texts only start to overtake Greek documents in quantity in the seventh and eighth centuries, when all kinds of documents are issued in Coptic. Through the Coptic material we also gain additional information about church affairs and the organisation and daily management of the monasteries. At this time it can be said that the vast majority of people was speaking Coptic, and Coptic therefore offers the best window onto the daily life and experiences of ordinary Egyptians.

73 See Rāgib, Sauf-conduits and also Diem, Einige frühe $141 \mathrm{ff}$., and, especially for the usual formulary for a passport, 144 .

74 As a special levy? That the amir is looking for donkeys is stated in P.Lond.Copt. I 529.5-6. The writer George gives careful instructions how to bring the donkey (not to go on the road, to go at night, not to tell anybody in the monastery) to avoid being seen by anyone. 


\section{Appendix 1: Three Texts (with some additions and emendations)}

\section{P.Ryl.Copt. 390}

1 // THPHNH NAK EBO

2 ITN חNOYTE TITAMO

3 MMOK $x \in \pi$ п)

4 поо $\lambda$ 入опон

5 amoY ępal $)$ d)

660 гагтні мпоо

7 [аүळ?] мпєр60 NaTel (or NaTI) 75

(1) "Peace (

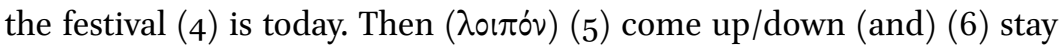
today with me. (7) [And?] stay not (longer) without coming (= do not delay to come)."

\section{O.CrumST 390}

1 Тா[P] OоскINe $\bar{M}$

2 памеріт N

3 CON $x \in$ дїє $е в о \lambda$

4 2ITOOTK $x \in$ eINABCW

5 eракате a.//.?़ाє

6 N2HT dį̈е ecooY N

$7 \quad \Delta \mathrm{laBOY \lambda OC} \mathrm{2N} \mathrm{TE2lH}$

8 NTEPIaחanta epooY

9 वІBOK $<\epsilon>2 € \epsilon B O \lambda$

10 वाп्T

5 for a. //eı (Crum) 5 read aleı $€$ ? 9 2 changed (Crum)

9 in edition: аıвюк $2 € є$ во $\lambda$

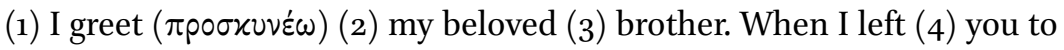

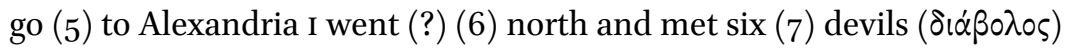

75 For a photograph, see P.Ryl.Copt. pl. 6. Unfortunately the end of line 7 is not visible on the plate. Therefore it could either read NaTel or NaTl (which is only an orthographic variant and does not affect the meaning). 
on the road (8) and while I met ( $\dot{\alpha} \pi \alpha \nu \tau \dot{\alpha} \omega)$ them (9) I was about to vanish (run away) (10) and I ran [

\section{O.Medin.HabuCopt. 82}

1 \$ аNOK песNTE

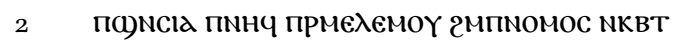

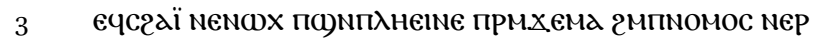

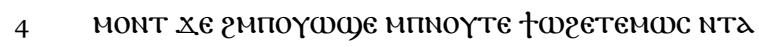

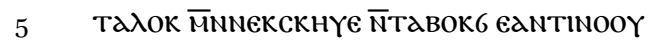

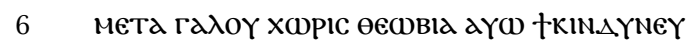

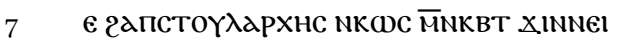

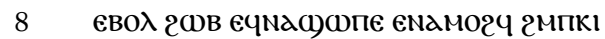

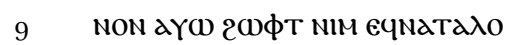

10 NaN тпн()є ерої тпн()є ерок

11 aүळ $\bar{\Gamma} \Gamma$ TNTOMMHN NKерат

12 CE NNOYB NAK MாП) NXEMa

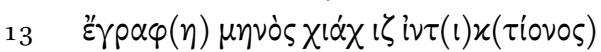

14 i

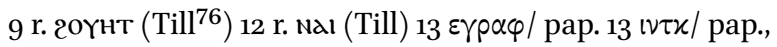
r. $i v \delta(\iota) x(\tau$ íovos)

(1) "I, Pesenthius, (2) son of Sia, the sailor, the man of Elemou, in the district (vouós) of Koptos, (3) write to Enoch, son of Pleine, the man of Jēme, in the district (vouós) of Ermont, (4) saying: By the will of God, I

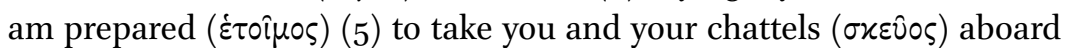
and convey you to Antinoe (6) safely ( $\mu \varepsilon \tau \dot{\alpha} x \alpha \lambda \circ \hat{)})$, barring an act of

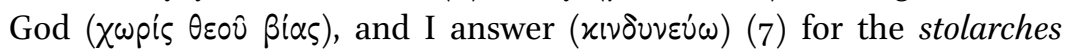
( $\sigma \tau \lambda \lambda \alpha p X \eta \varsigma)$ of Kos and Koptos. From the departure (8) we shall pay jointly (xovvós) every expense, (9) and every passenger that will come aboard (10) to us-half shall be for me and half for you. (11-12) And you shall pay for yourself eighteen gold carats ( $x \varepsilon \rho \alpha ́ \tau i o v) ~(12)$ in the standard of Jēme.

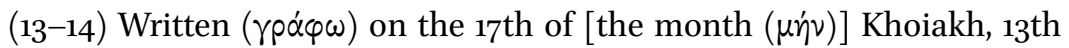

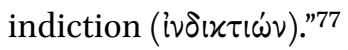

$76 \quad$ Till, Zu den Coptic 151.

77 Translation according to O.Medin.HabuCopt. 82, p. 17, with the addition of Till's corrections and the adding of the Greek terms (and line numbers). 


\section{Bibliography}

\section{Primary Sources}

Sawīrus ibn al-Muqaffa', History of the patriarchs of the Coptic Church of Alexandria III (Patrologia Orientalis 5), ed. B. Evetts, Paris 1910.

\section{Secondary Sources}

Allam, S., 'Observations on civil jurisdiction in Late Byzantine and Early Arabic Egypt,' in J. Johnson (ed.), Life in a multi-cultural society: Egypt from Cambyses to Constantine and beyond (Studies in Ancient Oriental Civilization 51), Chicago 1992, 1-8.

Bagnall, R.S., Egypt in late antiquity, Princeton 1993.

Boud'hors, A., L'apport de papyrus postérieurs à la conquête arabe pour la datation des ostraca coptes de la tombe TT29, in P.M. Sijpesteijn et al (eds.), From Al-Andalus to Khurasan: Documents from the medieval Muslim world, Leiden and Boston 2007, 115-129.

Delattre, A., Les "lettres de protection" coptes, in B. Palme (ed.), Akten des 23. Internationalen Papyrologen-Kongresses. Wien, 22.-28. Juli 2001, Vienna 2007, 173-178.

Diem, W., Einige frühe amtliche Urkunden aus der Sammlung Papyrus Erzherzog Rainer (Wien), in Le Muséon 97 (1984), 109-158.

Förster, H., Wörterbuch der griechischen Wörter in den koptischen dokumentarischen Texten (Texte und Untersuchungen zur Geschichte der altchristlichen Literatur, vol. 148), Berlin and New York 2002.

Heurtel, C., Que fait Frange dans la cour de la tomb тт 29? Fouilles dans la cour de la tombe тт 29, in C. Cannuyer (ed.), Cahiers de la Bibliothéque Copte 13: Études Coptes VIII, Lille and Paris 2003, 177-204.

Köpp-Junk, H., Reisen im Alten Ägypten. Reisekultur, Fortbewegungs- und Transportmittel in pharaonischer Zeit (Göttinger Orientforschungen, IV. Reihe: Ägypten 55), Wiesbaden 2014.

Kotsifou, C., Papyrological evidence of travelling in Byzantine Egypt, in A. McDonald and C. Riggs (eds.), Current research in Egyptology 2000 (BAR International Series 909), Oxford 2000, 57-64.

Krause, M., Die Kirchenvisitationsurkunden. Ein neues Formular in der Korrespondenz des Bischofs Abraham von Hermonthis, in S. Wenig (ed.) Studia in honorem Fritz Hintze (Meroitica 12), Berlin 1990a, 225-236.

_. Die ägyptischen Klöster. Bemerkungen zu den Phoibammon-Klöstern in Theben-West und den Apollon-Klöstern, in W. Godlewski (ed.), Coptic studies. Acts of the Third International Congress of Coptic Studies, Warsaw 199ob, 203-207.

MacCoull, L.S., Coptic Egypt during the Persian occupation: The papyrological evidence, in L.S. MacCoull (ed.), Coptic perspectives on late antiquity, Aldershot 1993, 307-313. 
Palme, B., Asyl und Schutzbrief im spätantiken Ägypten, in M. Dreher (ed.), Das Antike Asyl. Kultische Grundlagen, rechtliche Ausgestaltung und politische Funktion (Akten der Gesellschaft für griechische und hellenistische Rechtsgeschichte 15), Köln 2003, 203-236.

Peel, M.L., Dayr Epiphanius, in A.S. Atiya (ed.), The Coptic encyclopedia 3, New York 1991, 800-802.

Rāgib, Y., Sauf-conduits d'Égypte omeyyade et abbasside, in Annales Islamologiques 31 (1997), 143-168.

Richter, T.S., Spätkoptische Rechtsurkunden neu bearbeitet (III): P.Lond.Copt. I 487Arabische Pacht in koptischem Gewand, in Journal for juristic papyrology 33 (2003), 213-230.

Schaten, S., Reiseformalitäten im frühislamischen Ägypten, in Bulletin de la société d'archeologie Copte 37 (1998), 91-100.

Schmelz, G., Kirchliche Amtsträger im spätantiken Ägypten nach den Aussagen der griechischen und koptischen Papyri und Ostraka (Archiv für Papyrusforschung Beiheft 13), Munich and Leipzig 2002.

Selander, A.K., Reisetätigkeit nach den koptischen dokumentarischen Texten, Unpublished Master's Thesis, Vienna 2006.

—. Die koptischen Schutzbriefe, in C. Kreuzsaler, B. Palme, and A. Zdiarsky (eds.), Stimmen aus dem Wüstensand. Briefkultur im griechisch-römischen Ägypten (Nilus 17), Vienna 2010, 99-104.

Spiegelberg, W., Besprechung von O.Crum, in Oriental Literaturzeitung 6 (1903) 59-69. Till, W.C., Zu den Coptic Ostraca from Medinet Habu, in Orientalia 24 (1955), 146-155. Vinson, S., The Nile boatman atwork. 1200 BC-40o CE (Müncher ägyptologische Studien 48), Mainz 1998.

Winlock, H.E. and W.E. Crum, The monastery of Epiphanius at Thebes. Part I. The Metropolitan Museum of Art Egyptian expedition, New York 1926. 